\title{
Effect of Insoluble Calcium Concentration on Rennet Coagulation Properties of Milk
}

\author{
J. Choi, ${ }^{\star}$ D. S. Horne, $†$ and J. A. Lucey ${ }^{\star 1}$ \\ *Department of Food Science, University of Wisconsin-Madison, 1605 Linden Drive, Madison 53706 \\ †Charis Food Research, Hannah Research Park, Ayr, Scotland, KA6 5HL
}

\begin{abstract}
Rennet-induced gels were made from milk acidified to various $\mathrm{pH}$ values or milk at $\mathrm{pH} 6.0$ that had added EDTA. The objective was to examine the effect of removing insoluble $\mathrm{Ca}$ (INS Ca) from casein micelles (CM) on rennet gelation properties. For the $\mathrm{pH}$ trial, diluted lactic acid was added to reconstituted skim milk to decrease the $\mathrm{pH}$ to $6.4,6.0,5.8,5.6$, and 5.4. For the EDTA trial, EDTA was slowly added $(0,2,4$, and 6 $\mathrm{m} M$ ) to reconstituted skim milk, and the final $\mathrm{pH}$ values were subsequently adjusted to $\mathrm{pH}$ 6.0. Dynamic low amplitude oscillatory rheology was used to monitor gel development. The Ca content of CM and rennet wheys made from these milks was measured using inductively coupled plasma spectroscopy. The INS Ca content of milk was altered by the acidification $\mathrm{pH}$ values or level of EDTA added. In all samples, the storage modulus $\left(G^{\prime}\right)$ exhibited a maximum (GM), with a decrease in $G^{\prime}$ during longer aging times. Gels made at $\mathrm{pH} 6.4 \mathrm{had}$ higher GM compared with gels made at $\mathrm{pH} 6.7$ probably due to the reduction in electrostatic repulsion, whereas the INS Ca content only slightly decreased. The highest GM value of gels was observed at $\mathrm{pH} 6.4$ and the GM value decreased with decreasing $\mathrm{pH}$ from 6.4 to 5.4. This was due to an excessive loss of INS Ca from CM. There was a decrease in GM with the increase in the concentration of added EDTA, which was probably due to the loss of colloidal calcium phosphate, which weakens the integrity of CM. Loss tangent (LT) values at GM increased with a reduction in milk $\mathrm{pH}$ and the addition of EDTA to milk. Rennet gels at the point of the GM were subjected to constant low shearing to fracture the gels. With a reduction in INS Ca content, the yield stress decreased, whereas LT values increased indicating a weaker, more flexible casein network. Microstructure of rennet-induced gels near the GM point and 2 to $10 \mathrm{~h}$ after this point was studied using fluores-
\end{abstract}

Received December 4, 2006.

Accepted January 29, 2007.

${ }^{1}$ Corresponding author: jalucey@facstaff.wisc.edu cence microscopy. At GM, gels made from milk acidified to $\mathrm{pH} 6.4$ exhibited more branched, interconnected networks, whereas strands and clusters became larger with a reduction in milk $\mathrm{pH}$ to 5.4. Gels made from milk with EDTA added had more finely dispersed protein clusters compared with gels made from milk with no EDTA added. These microscopic observations supported the effect of loss of INS Ca on GM and LT. There was a decrease in apparent interconnectivity between strands in gel microstructure during aging, which agreed with the decrease in $\mathrm{G}^{\prime}$ after GM. It can be concluded that low levels of solubilization of INS Ca and the decrease in milk $\mathrm{pH}$ resulted in an increase in GM. With greater losses of INS Ca there was excessive reduction in cross-linking within $\mathrm{CM}$, which resulted in weaker, more flexible rennet gels. This complex behavior cannot be explained by adhesive hard sphere models for CM or rennet gels made from these CM.

Key words: casein micelle, insoluble calcium, rheology, rennet coagulation

\section{INTRODUCTION}

Gelation of caseins is the first key step in cheese manufacture. The addition of chymosin to the milk initiates the destabilization of casein micelles (CM) via hydrolysis of $\kappa-\mathrm{CN}$, which is the first phase of rennet coagulation (Dalgleish, 1992). Once a sufficient degree of destabilized paracasein micelles are produced, aggregation begins, which is the second phase (Hyslop, 2003), and this leads to the formation of a 3-dimensional spacefilling gel, which is the third phase (Horne and Banks, 2004). In contrast to the first and second stages of rennet coagulation, there have been fewer studies on the third stage of curd development. Rennet-induced milk gels are viscoelastic, and their dynamic rheological properties can be characterized using both the viscous and elastic components. In general, these 2 shear moduli sigmoidally increase with time during rennet curd formation.

The native CM has been treated as an adhesive hard sphere particle (de Kruif, 1998). In the hard sphere model, stability and instability properties of native CM 
are ascribed to the hairy layer ("brush") of $\kappa$-CN on their surface. This model has been used to quantitatively model the viscosity of renneted skim milk as a function of time where it goes through a minimum and then an increase in viscosity before a gel is formed. However, the hard sphere model is thermodynamic in origin and it has no inherent time scale. It is not able to predict behavior after the gel point; for example, dynamics of network formation. Its limitations were well documented in acidified milk gel formation; that is, it cannot take into account the importance of the internal structure of $\mathrm{CM}$ on gel properties (Horne, 2003).

In the dual-binding model for the structure and formation of CM (Horne, 1998), individual CN molecules are considered as block copolymers. Micellar assembly is viewed as a polymerization process occurring as a result of hydrophobic interactions or by bridging via insoluble calcium (INS Ca) phosphate (Horne, 1998). The balance between electrostatic repulsion and attractive hydrophobic interaction controls the degree of incorporation of individual CN molecules in the assembly of CM. Thus, the dual-binding model for CM views INS $\mathrm{Ca}$ as a key bridging material. It is well known that INS $\mathrm{Ca}$, or colloidal calcium phosphate as it is often called, is solubilized as milk pH decreases (Dalgleish and Law, 1989). It can therefore be predicted that the loss of INS Ca from within CM should modify the internal structural integrity and alter the mechanical properties of gels made from these modified CM. This aspect is quite relevant for textural properties of cheese made from milk renneted at lower $\mathrm{pH}$; that is, cheese made from direct acidified milk (Choi et al., 2004).

Rheological properties of rennet-induced gels have been extensively studied usually at the normal milk pH (Horne, 1995; Esteves et al., 2001; Udabage et al., 2001; Srinivasan and Lucey, 2002), and also at lower pH values (van Hooydonk et al., 1986; Zoon et al., 1989; Roefs et al., 1990; Mellema et al., 2000, 2002; Vetier et al., 2000). Nonetheless, the effect of INS Ca in rennet gelation properties has not been extensively studied and the effect of altering renneting $\mathrm{pH}$ and loss of INS $\mathrm{Ca}$ from $\mathrm{CM}$ on rennet gelation properties have not been interpreted in the context of the new dual-binding model for CM.

It is our hypothesis that modifications of internal micellar interactions could affect the gelation properties of rennet-induced gels. The objective of this study was to examine the effect of removing INS Ca from CM on the rennet gelation properties of skim milk. Two approaches were used. In the first, the INS Ca content of CM was altered by acidification of milks with diluted lactic acid. However, because $\mathrm{pH}$ and INS Ca content vary in these samples, we did another treatment where
$\mathrm{pH}$ was constant $(\sim 6.0)$ and EDTA was used to chelate $\mathrm{Ca}$.

\section{MATERIALS AND METHODS}

\section{Materials}

Low-heat skim milk powder was supplied by Dairy Farmers of America (Fresno, CA). Soybean trypsin inhibitor, type I-S (T 9003), and acridine orange were purchased from Sigma Chemical Co. (St. Louis, MO). Commercial double-strength fermentation-produced chymosin (Chymostar) was supplied by Rhodia Inc. (Madison, WI). Lactic acid (88\% wt/wt) was supplied by Chr. Hansen (Milwaukee, WI); EDTA and $\mathrm{CaCl}_{2} \cdot 2 \mathrm{H}_{2} \mathrm{O}$ were purchased from Fisher Scientific (Fairlawn, NJ).

\section{Preparation of Milk Samples}

Low-heat skim milk powder was reconstituted in demineralized water to $8.7 \%$ (wt/wt) solids, and stirred at room temperature for $30 \mathrm{~min} ; \mathrm{NaN}_{3}(0.2 \mathrm{mg} / \mathrm{mL})$ and soybean trypsin inhibitor $(0.15 \mathrm{mg} / \mathrm{mL})$ were added to prevent bacterial growth and inhibit plasmin activity, respectively. The milk solutions were equilibrated by stirring at $32^{\circ} \mathrm{C}$ for $2 \mathrm{~h}$ using a magnetic stirring unit, and immediately cooled to $\sim 4^{\circ} \mathrm{C}$. For the experiments in which skim milk solutions were acidified (i.e., the $\mathrm{pH}$ trial), predetermined amounts of diluted lactic acid (1:4, acid:water) were slowly added to milk samples to decrease the $\mathrm{pH}$ of milk to $6.4,6.0,5.8,5.6$, and 5.4; about half the estimated total amount of lactic acid that was required was initially added and the remaining acid was slowly added until the desired $\mathrm{pH}$ was reached. For the addition of EDTA to cold $\left(\sim 4^{\circ} \mathrm{C}\right)$ milk (i.e., EDTA trial), the EDTA was slowly added to obtain final concentrations of $0,2,4$, and $6 \mathrm{~m} M$ EDTA, and the milk was stirred for $1 \mathrm{~h}$. Predetermined amounts of diluted lactic acid were slowly added to milks that had added EDTA to have all samples at $\mathrm{pH}$ 6.0. All milk samples were then warmed to $32^{\circ} \mathrm{C}$, and their $\mathrm{pH}$ values were rechecked and adjusted to be within \pm 0.05 of the desired $\mathrm{pH}$ values. Milk samples were stored at $4^{\circ} \mathrm{C}$ for about 6 $\mathrm{h}$ to allow for equilibration. To help reduce the gelation time, $50 \mu \mathrm{g} / \mathrm{mL}$ of $\mathrm{CaCl}_{2} \cdot 2 \mathrm{H}_{2} \mathrm{O}$ was added at the time that $\mathrm{NaN}_{3}$ was added for the $\mathrm{pH}$ trial, and $120 \mu \mathrm{g} / \mathrm{mL}$ of $\mathrm{CaCl}_{2} \cdot 2 \mathrm{H}_{2} \mathrm{O}$ was added $30 \mathrm{~min}$ before the addition of rennet for the EDTA trial.

\section{Chemical Analyses}

Total solids, fat, CN, and total protein were determined as described by Marshall (1992). Soluble Ca in milk samples was defined as Ca content in rennet whey $\times$ correction factor $(0.998)$ for the volume of $\mathrm{CN}$ precipi- 
CHOI ET AL.

Table 1. Chemical composition of reconstituted skim milks acidified to different $\mathrm{pH}$ values

\begin{tabular}{lcccccccr}
\hline & \multicolumn{7}{c}{$\mathrm{pH}$ of acidification } & \\
\cline { 2 - 7 } & 6.7 & 6.4 & 6.0 & 5.8 & 5.6 & 5.4 & SEM $^{1}$ & LSD $^{2}$ \\
\hline Total solids, \% & $8.76^{\mathrm{ab}}$ & $8.71^{\mathrm{ab}}$ & $8.78^{\mathrm{ab}}$ & $8.82^{\mathrm{a}}$ & $8.69^{\mathrm{b}}$ & $8.69^{\mathrm{b}}$ & 0.04 & 0.12 \\
Fat, \% & $0.09^{\mathrm{a}}$ & $0.0^{\mathrm{a}}$ & $0.08^{\mathrm{a}}$ & $0.07^{\mathrm{a}}$ & $0.07^{\mathrm{a}}$ & $0.07^{\mathrm{a}}$ & 0.01 & 0.05 \\
Total protein, \% & $3.08^{\mathrm{a}}$ & $3.09^{\mathrm{a}}$ & $3.09^{\mathrm{a}}$ & $3.10^{\mathrm{a}}$ & $3.08^{\mathrm{a}}$ & $3.08^{\mathrm{a}}$ & 0.02 & 0.08 \\
Casein, \% & $2.41^{\mathrm{a}}$ & $2.44^{\mathrm{a}}$ & $2.43^{\mathrm{a}}$ & $2.45^{\mathrm{a}}$ & $2.43^{\mathrm{a}}$ & $2.43^{\mathrm{a}}$ & 0.02 & 0.08 \\
Total Ca, $\mathrm{mg} / 100 \mathrm{~mL}$ & $99.8^{\mathrm{ab}}$ & $97.9^{\mathrm{c}}$ & $100.2^{\mathrm{a}}$ & $99.4^{\mathrm{ab}}$ & $99.0^{\mathrm{bc}}$ & $98.3^{\mathrm{c}}$ & 0.3 & 1.04 \\
Insoluble Ca, $\mathrm{mg} / 100 \mathrm{~mL}$ & $704^{\mathrm{a}}$ & $66.0^{\mathrm{b}}$ & $45.9^{\mathrm{c}}$ & $34.9^{\mathrm{d}}$ & $21.9^{\mathrm{e}}$ & $11.9^{\mathrm{f}}$ & 1.0 & 3.25 \\
Soluble Ca, $\mathrm{mg} / 100 \mathrm{~mL}$ & $29.4^{\mathrm{a}}$ & $31.9^{\mathrm{a}}$ & $54.2^{\mathrm{b}}$ & $64.4^{\mathrm{c}}$ & $77.0^{\mathrm{d}}$ & $86.4^{\mathrm{e}}$ & 1.0 & 3.34 \\
\hline
\end{tabular}

${ }^{\mathrm{a}-\mathrm{f}}$ Means with different superscript letters within the same row are significantly different $(P<0.05)$.

${ }^{1} \mathrm{SEM}=$ standard error of the mean

${ }^{2} \mathrm{LSD}=$ least significant difference.

tate; insoluble $\mathrm{Ca}=$ total $\mathrm{Ca}$ in milk - soluble $\mathrm{Ca}$ in milk. For Ca analysis, ashed samples were solubilized with $25 \% \mathrm{HNO}_{3}$ and diluted to $1 \% \mathrm{HNO}_{3}$ with doubledeionized water. Concentrations of $\mathrm{Ca}$ were quantified by inductively coupled argon plasma emission spectroscopy (model Varian Vista-Pro AX, Varian Australia Pty Ltd., Clayton, Victoria, Australia). Wavelength used for $\mathrm{Ca}$ analysis was $317.9 \mathrm{~nm}$.

\section{Rheological Properties}

A universal dynamic spectrometer (Paar Physica UDS 200, Physica Messtechnik GmbH, Stuttgart, Germany) was used to determine the rheological properties of rennet gels. During deformation, the nondestructive rheological properties can be determined by low amplitude dynamic oscillation with the measurement of the storage modulus $\left(\mathbf{G}^{\prime}\right)$ and loss tangent (LT), which is the ratio of viscous to elastic properties. The cup and bob measuring geometry consisting of 2 coaxial cylinders (one of external diameter $25.0 \mathrm{~mm}$, the other of internal diameter $27.5 \mathrm{~mm}$ ) was used. Treated milk samples that had been stored at $4^{\circ} \mathrm{C}$ for $\sim 6 \mathrm{~h}$ were warmed to $40^{\circ} \mathrm{C}$ for $1 \mathrm{~h}$, cooled to $32^{\circ} \mathrm{C}$, and held for 15 $\min$ at $32^{\circ} \mathrm{C}$. Then, $43.1 \mu \mathrm{L}$ of diluted rennet $(1: 120$ for $\mathrm{pH}$ trial; 1:75 for EDTA trial) was added to $20 \mathrm{~mL}$ of milk. After addition of rennet to milk, the mixture was stirred for 2 min and $12.75 \mathrm{~mL}$ of milk sample was transferred to the measuring geometry of the rheometer. Vegetable oil was placed on the surface to prevent evaporation. Samples were oscillated at a frequency of $0.1 \mathrm{~Hz}$, strain applied was $0.05 \%$, and measurements were taken every min until gels attained their maximum $\mathrm{G}^{\prime}$ (GM). The large deformation properties of rennet gels made in situ were also determined. When gels attained their GM, a constant shear rate of $0.01 \mathrm{~s}^{-1}$ was applied to the gel. Yield stress was defined as the point when the shear stress started to decrease. The constant shear rate technique for determining an apparent yield stress and shear deformation at yielding has been described previously (Lucey et al., 1997).

\section{Fluorescence Microscopy}

Acridine orange $(0.2 \% \mathrm{wt} / \mathrm{vol})$, dissolved in water, was used as fluorescent protein dye. Three hundred microliters of acridine orange was added to $50 \mathrm{~mL}$ of milk sample and mixed for $15 \mathrm{~min}$. Diluted rennet was added

Table 2. Chemical composition of reconstituted skim milk with different EDTA concentrations added to milk at $\mathrm{pH} 6.0$

\begin{tabular}{|c|c|c|c|c|c|c|c|}
\hline & \multirow{2}{*}{$\begin{array}{c}\text { Normal } \\
\text { milk } \\
(\mathrm{pH} \mathrm{6.7)}\end{array}$} & \multicolumn{4}{|c|}{ EDTA concentration $(\mathrm{m} M)$} & \multirow[b]{2}{*}{$\mathrm{SEM}^{1}$} & \multirow[b]{2}{*}{$\mathrm{LSD}^{2}$} \\
\hline & & 0 & 2 & 4 & 6 & & \\
\hline Total solids, \% & $8.62^{\mathrm{c}}$ & $8.67^{\mathrm{bc}}$ & $8.76^{\mathrm{abc}}$ & $8.82^{\mathrm{ab}}$ & $8.84^{\mathrm{a}}$ & 0.04 & 0.15 \\
\hline Fat, \% & $0.08^{\mathrm{a}}$ & $0.08^{\mathrm{a}}$ & $0.07^{\mathrm{a}}$ & $0.08^{\mathrm{a}}$ & $0.09^{\mathrm{a}}$ & 0.01 & 0.04 \\
\hline Total protein, \% & $3.06^{\mathrm{c}}$ & $3.04^{\mathrm{c}}$ & $3.08^{\mathrm{bc}}$ & $3.11^{\mathrm{ab}}$ & $3.14^{\mathrm{a}}$ & 0.01 & 0.04 \\
\hline Casein, \% & $2.39^{\mathrm{a}}$ & $2.40^{\mathrm{a}}$ & $2.40^{\mathrm{a}}$ & $2.41^{\mathrm{a}}$ & $2.42^{\mathrm{a}}$ & 0.01 & 0.04 \\
\hline Total Ca, mg/100 mL & $98.3^{\mathrm{a}}$ & $97.2^{\mathrm{a}}$ & $98.6^{\mathrm{a}}$ & $95.3^{\mathrm{a}}$ & $96.4^{\mathrm{a}}$ & 1.4 & 4.69 \\
\hline Insoluble $\mathrm{Ca}, \mathrm{mg} / 100 \mathrm{~mL}$ & $74.1^{\mathrm{a}}$ & $48.3^{\mathrm{b}}$ & $43.6^{\mathrm{b}}$ & $30.5^{\mathrm{c}}$ & $20.6^{\mathrm{d}}$ & 2.4 & 7.72 \\
\hline Soluble Ca, mg/100 mL & $24.1^{\mathrm{d}}$ & $48.8^{c}$ & $55.0^{\mathrm{c}}$ & $64.8^{\mathrm{b}}$ & $75.8^{\mathrm{a}}$ & 2.5 & 8.07 \\
\hline
\end{tabular}

${ }^{\mathrm{a}-\mathrm{d}}$ Means with different superscript letters within the same row are significantly different $(P<0.05)$.

${ }^{1} \mathrm{SEM}=$ standard error of the mean.

${ }^{2} \mathrm{LSD}=$ least significant difference. 
with stirring for $2 \mathrm{~min}$. A few drops of the mixture were transferred to a concave slide and then incubated at $32^{\circ} \mathrm{C}$ for the predetermined time. The microstructure of rennet-induced gels was observed using a fluorescence microscope (Axioskop 40, Carl Zeiss Light Microscopy, Gottingen, Germany) equipped with motorized stage (z-drive) (Axioskop z mot plus, Carl Zeiss Inc., New York, NY). A series of images from different positions in the gel matrix were acquired with the aid of z-stack module (AxioVision 3.1, Carl Zeiss Vision GmbH, Munchen-Hallbergmoos, Germany). To eliminate outof-focus light in fluorescence microscopy, the nearestneighbor algorithm as a 3-dimensional deconvolution was applied (Verveer et al., 1999; Schaefer et al., 2001). This algorithm is based on a simple 2-dimensional subtraction of the out-of-focus information, which is applied to all image planes in the z-stack (Carl Zeiss Vision, 2002).

\section{Statistical Analysis}

An ANOVA was carried out using the SAS program (SAS Institute, 2001) to see if there were effects of acidification $\mathrm{pH}$ values or addition of EDTA on milk and mineral composition, and on rheological properties. The differences in least squares means were determined using LSD. Significance was established at $P<0.05$.

\section{RESULTS}

\section{Milk Composition}

Because milk composition, including fat and CN contents, is well known to affect coagulation properties of milk (Choi and Ng-Kwai-Hang, 2003), reconstituted skim milks were used in this study; the composition of the milk is shown in Tables 1 and 2. As expected, no significant $(P>0.70)$ differences in fat and $\mathrm{CN}$ contents were found in the various samples used for the $\mathrm{pH}$ and EDTA trials. The slightly lower CN content in the EDTA trials compared with the $\mathrm{pH}$ trials suggests that the total Ca content of milk in the EDTA trial would be expected to be slightly lower than that in $\mathrm{pH}$ trial, which was confirmed in Table 2 . The $\mathrm{N}$ content of EDTA is about $7.52 \%$, and its contribution to the total protein content in EDTA trial was estimated to be about 0.035 , 0.071 , and $0.107 \mathrm{~g}$ of protein per $100 \mathrm{~mL}$ of milk for 2 , 4 , and $6 \mathrm{~m} M$ EDTA, respectively. The contribution of EDTA to total protein (Table 2) was not taken into consideration in the results shown in Table 2 . The CN content in the EDTA trial was determined by assuming that N in EDTA behaved as non-CN nitrogen. Dilution effects on the total solids by the addition of lactic acid in the $\mathrm{pH}$ trial (Table 1 ) and contribution by the addition of
Table 3. Mean squares and probability for rheological properties of rennet-induced gels

\begin{tabular}{lrccr}
\hline Source & df & GM $^{1}$ & $\mathrm{LT}^{1}$ & $\sigma_{\text {yield }}{ }^{1}$ \\
\hline pH values & 5 & $2,442.1^{* *}$ & $0.12^{* *}$ & $1,480^{* * *}$ \\
Error & 12 & 3.2 & 0.0003 & 1.7 \\
EDTA concentrations & 4 & $1,333^{* *}$ & $0.025^{* *}$ & $1,148^{* *}$ \\
Error & 10 & 18.85 & 0.0001 & 33.48
\end{tabular}

${ }^{1} \mathrm{GM}=$ maximum storage modulus; $\mathrm{LT}=$ loss tangent $; \sigma_{\text {yield }}=$ yield stress.

$* * P<0.0001$.

EDTA to total solids (Table 2) were not taken into account.

\section{Solubilization of Insoluble Ca from Casein Micelles}

Tables 1 and 2 show the degree of solubilization of $\mathrm{Ca}$ from $\mathrm{CM}$ into the serum phase as a function of milk $\mathrm{pH}$ or concentration of added EDTA. It should be noted that the total $\mathrm{Ca}$ contribution from $\mathrm{Ca}$ chloride was estimated to be $1.36 \mathrm{mg} / 100 \mathrm{~g}$ of milk in the $\mathrm{pH}$ trial and $3.27 \mathrm{mg} / 100 \mathrm{~g}$ of milk in the EDTA trial. Total Ca content of milk was similar in both trials. As expected, acidification of milk samples and the addition of EDTA had statistically significant $(P<0.01)$ effects on the INS $\mathrm{Ca}$ content. For the $\mathrm{pH}$ trial, the INS Ca content of milk at $\mathrm{pH} 6.7$ was $70.4 \mathrm{mg} / 100 \mathrm{~mL}$ and the INS Ca content decreased to $11.9 \mathrm{mg} / 100 \mathrm{~mL}$ in milk at $\mathrm{pH} 5.4$. The INS Ca content of milk at $\mathrm{pH} 6.0$ with no added EDTA was $48.3 \mathrm{mg} / 100 \mathrm{~mL}$ and the INS Ca content decreased to $20.6 \mathrm{mg} / 100 \mathrm{~mL}$ with the addition of 6 $\mathrm{m} M$ EDTA.

\section{Small Deformation Rheological Properties of Rennet-Induced Gels}

The effects of different $\mathrm{pH}$ values of milk (Table 3) or the various concentrations of EDTA added to milk (Table 3) on the GM values of rennet gels were found to be highly significant $(P<0.001)$. The $\mathrm{G}^{\prime}$ profiles of milk samples acidified to different $\mathrm{pH}$ values and milks with different concentrations of EDTA are shown in Figures 1a and 2a, respectively. In all samples, it was observed that the $\mathrm{G}^{\prime}$ profile exhibited a maximum and thereafter, decreased (data not shown), presumably because of a reaction such as microsyneresis (Roefs et al., 1990). This decrease in $\mathrm{G}^{\prime}$ after the GM occurred sooner in low $\mathrm{pH}$ samples. The GM values at $\mathrm{pH} 6.7,6.4,6.0$, $5.8,5.6$, and 5.4 were $69,75,57,41,16$, and $6 \mathrm{~Pa}$, respectively (Figure 1a). The GM values of gels made from normal milk at $\mathrm{pH} 6.7$ were slightly lower than those of gels at $\mathrm{pH} 6.4(P<0.01)$. This result is in agreement with that of Zoon et al. (1989) and Mellema et al. (2000). The GM value of rennet gels was highest 

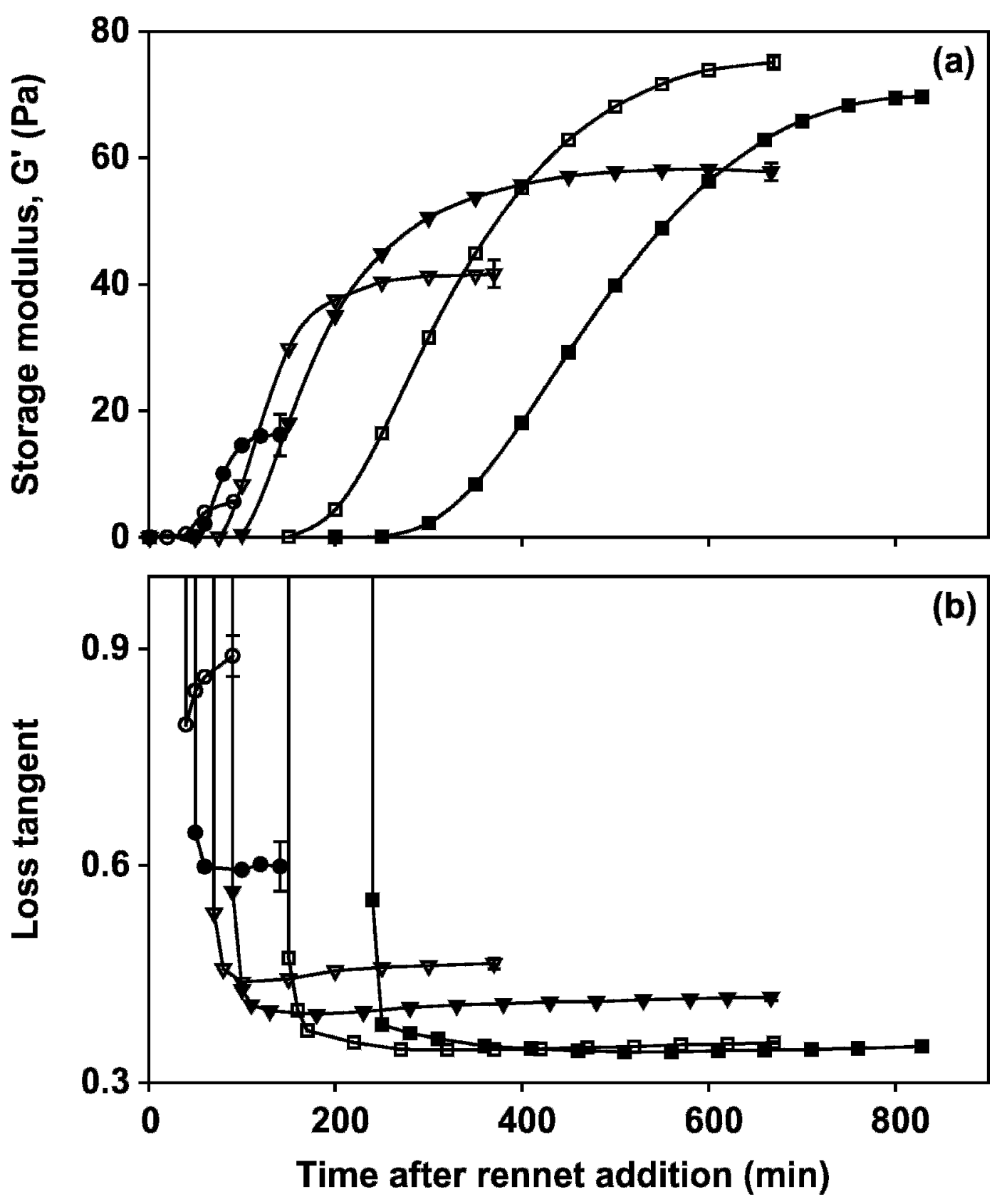

Figure 1. a) Storage modulus $\left(\mathrm{G}^{\prime}\right)$ and b) loss tangent (LT) as a function of time for rennet-induced milk gels made from milk acidified to $\mathrm{pH} 6.7(\square), 6.4(\square), 6.0(\nabla), 5.8(\nabla), 5.6(\bullet)$, and pH $5.4(\bigcirc)$. Results are means of triplicates with error bars for standard deviation.

at $\mathrm{pH} 6.4$ and decreased with decreasing $\mathrm{pH}$ from 6.4 to $5.4(P<0.01)$, which agrees with results of Zoon et al. (1989) and Vetier et al. (2000). The gelation time (Figure 1a), defined as the point when gel had a $\mathrm{G}^{\prime}$ of $\geq 0.1 \mathrm{~Pa}$, of milk samples at $\mathrm{pH} 6.7,6.4,6.0,5.8,5.6$, and 5.4 were $243,148,87,70,49$, and 34 min, respectively (Figure 1a), and increased with an increase in milk pH. This is in agreement with other reports (Zoon et al., 1989). The GM values of gels made from normal milk at $\mathrm{pH} 6.7$ and milks at $\mathrm{pH} 6.0$ with $0,2,4$, and $6 \mathrm{mM}$ EDTA were 76, 56, 42, 48, and $18 \mathrm{~Pa}$, respectively (Figure 2a). For both trials, the gels made from normal milk at pH 6.7 had slightly different GM values (76 and 69 $\mathrm{Pa}$ in the EDTA and $\mathrm{pH}$ trials, respectively) presumably due to the slightly different $\mathrm{CaCl}_{2}$ concentrations and rennet concentrations used in the 2 trials. The GM value for normal milk at $\mathrm{pH} 6.7$ was higher compared with all the EDTA-treated milks $(P<0.01)$. This was 

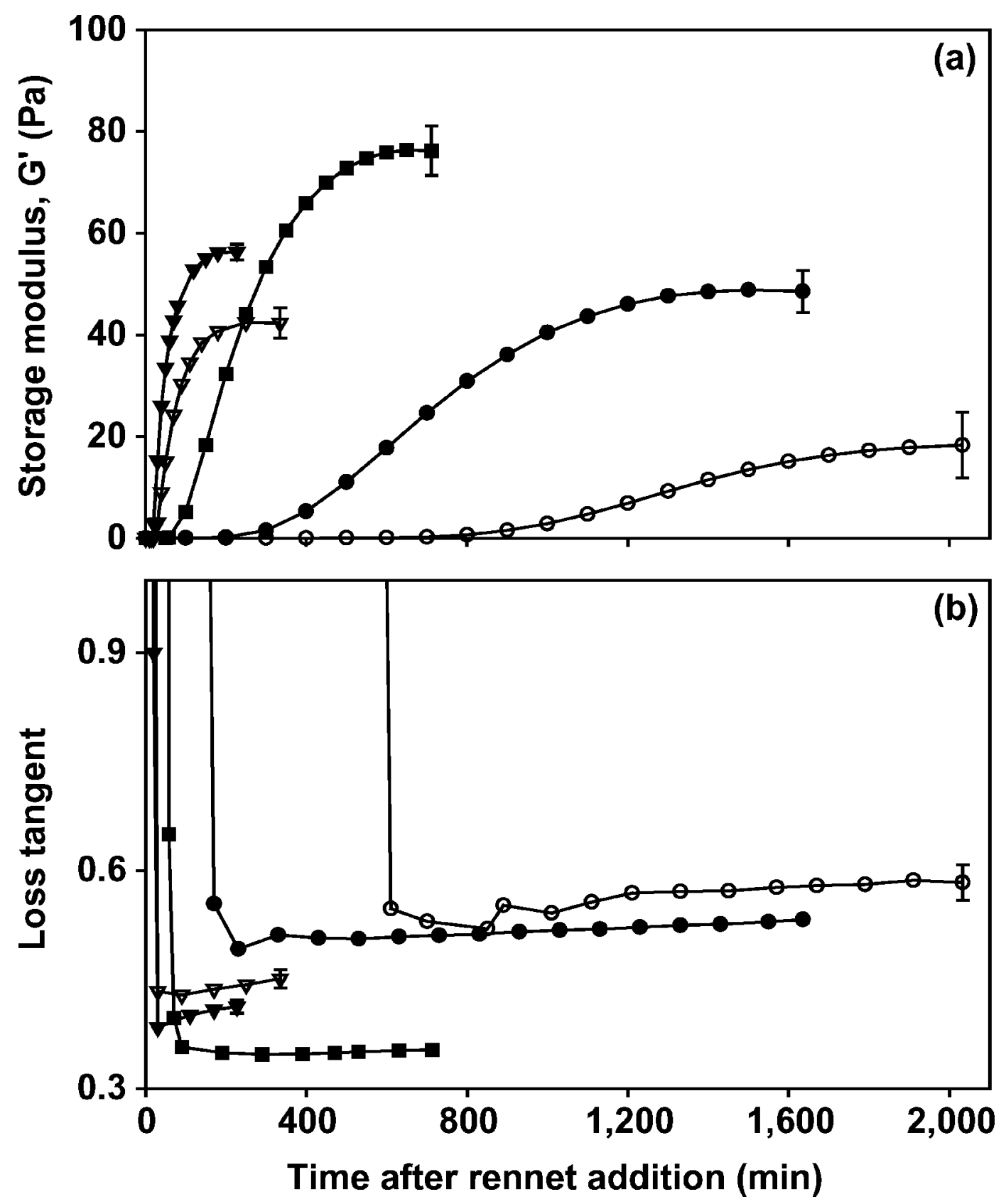

Figure 2. a) Storage modulus $\left(\mathrm{G}^{\prime}\right)$ and b) loss tangent (LT) as a function of time for rennet-induced milk gels made with different EDTA levels and subsequently adjusted to $\mathrm{pH} 6.0$; normal milk at $\mathrm{pH} 6.7(\boldsymbol{\square})$, and milk at $\mathrm{pH} 6.0$ with $0(\boldsymbol{\nabla}), 2(\nabla), 4(\bullet)$, and $6 \mathrm{mM}(\bigcirc)$ added EDTA. Results are means of triplicates with error bars for standard deviation.

probably due to the loss of CCP crosslinks by EDTA. Milk samples with $4 \mathrm{~m} M$ EDTA added had slightly higher (but not significant, $P>0.12$ ) GM values than milks with $2 \mathrm{mM}$ EDTA. The lowest GM values among the milk samples with added EDTA were obtained in the milks with $6 \mathrm{~m} M$ EDTA. The gelation time (Figure 2a) for milk samples at $\mathrm{pH} 6.0$ with 0,2 , 4, and $6 \mathrm{mM}$ EDTA added was 15, 21, 170, and 615 min, respectively.
The gelation time increased with an increase in the concentration of added EDTA. This was probably due to lower $\mathrm{Ca}^{2+}$ activity even after $\mathrm{CaCl}_{2}$ was added, because $\mathrm{Ca}^{2+}$ is critical for the aggregation of rennet-altered $\mathrm{CM}$ (Lucey and Fox, 1993).

The acidification of milk to different $\mathrm{pH}$ values or the concentration of EDTA added to milk had a highly significant effect $(P<0.001)$ on the LT values of rennet- 
induced gels at GM (Table 3). The LT profiles as a function of time for the $\mathrm{pH}$ trial are shown in Figure $1 b$. The LT values decreased at gelation and thereafter remained constant or slightly increased. The LT values after gelation increased with decreasing $\mathrm{pH}$. The LT values of rennet-induced gels at GM for milks acidified to $\mathrm{pH} 6.7,6.4,6.0,5.8,5.6$, and 5.4 were $0.35,0.35,0.41$, $0.46,0.59$, and 0.89 , respectively (Figure $1 b$ ). These LT values were significantly $(P<0.01)$ different from one another except the LT values for gels at $\mathrm{pH} 6.7$ and 6.4 $(P>0.74)$. The LT values after gelation in gels made from normal milk at $\mathrm{pH} 6.7$ and in gels made from milk at $\mathrm{pH} 6.0$ with $0,2,4$, and $6 \mathrm{~m} M$ EDTA were $0.35,0.41$, $0.45,0.53$, and 0.58 , respectively (Figure $2 b$ ). These LT values were significantly $(P<0.01)$ different.

\section{Large Deformation Rheological Properties of Rennet-Induced Gels}

Altering milk $\mathrm{pH}$ values or adding various concentrations of EDTA to milk had a highly significant effect on yield stress $(P<0.01)$ of rennet-induced gels as can be seen from the ANOVA results (Table 3). Shear stress profiles as a function of strain for rennet gels with different $\mathrm{pH}$ values are shown in Figure 3a. Yield stress values in rennet gels made with $\mathrm{pH} 6.7,6.4,6.0,5.8$, 5.6 , and 5.4 were $45,54,49,35,7$, and $2 \mathrm{~Pa}$, respectively. With a reduction in $\mathrm{pH}$ from 6.4 to 5.4, there was large decrease in yield stress from 54 to $2 \mathrm{~Pa}(P<0.01)$. Yield stress of rennet gels made from milk at $\mathrm{pH} 6.7$ were lower than those at $\mathrm{pH} 6.4$ and 6.0, and higher than those at $\mathrm{pH} 5.8,5.6$, and 5.4. The shear stress profiles for rennet gels made from milk at $\mathrm{pH} 6.0$ with EDTA added are shown in Figure 3b. The yield stress of gels made from normal milk ( $\mathrm{pH} 6.7$ ) was $54 \mathrm{~Pa}$, and the corresponding values in gels made at $\mathrm{pH} 6.0$ with 0 , 2 , 4, and $6 \mathrm{~m} M$ EDTA were $56,40,25$, and $10 \mathrm{~Pa}$, respectively. There was no significant $(P>0.62)$ difference in yield stress of gels made from milks at $\mathrm{pH} 6.7$ or $\mathrm{pH} 6.0$.

\section{Microstructure}

The micrographs of rennet-induced gels made with different milk $\mathrm{pH}$ values and levels of added EDTA are presented in Figures 4 and 5, respectively. Gels were examined at their GM and also several hours after the GM to understand possible structural changes during aging (i.e., microsyneresis). Microstructures observed at GM for $\mathrm{pH}$ trial are shown in Figures $4 \mathrm{a}, \mathrm{b}, \mathrm{c}, \mathrm{g}, \mathrm{h}$, and $\mathrm{i}$, and microstructures observed after GM ( 2 to 6 h) in Figures 4d, e, f, j, k, and l. Larger pores were seen as the $\mathrm{pH}$ decreased from 5.8 (Figure $4 \mathrm{~g}$ ) to 5.4 (Figure 4i). The micrographs for gels examined at the GM for the EDTA trial are shown in Figures 5a, b, c, g, and h and examined after GM ( $~ 3$ to $10 \mathrm{~h}$ ) are shown in Figure $5 \mathrm{~d}, \mathrm{e}, \mathrm{f}, \mathrm{i}$, and $\mathrm{j}$. In gels made from milk with EDTA added, there were more finely dispersed protein clusters and thinner strands (Figure 5c, g, and h) compared with gels made from milk with no EDTA added (Figure $5 \mathrm{a}$ and b). Micrographs obtained several hours after GM shows that considerable macroscopic changes had occurred compared with gels observed at GM. For both trials the apparent pore size of gels at GM became larger with aging.

\section{DISCUSSION}

The rennet gelation behavior of milk gels is influenced by many variables including $\mathrm{pH}$ and the INS Ca content. In this study we investigated the influence of reducing the INS Ca content at constant $\mathrm{pH}$ and when $\mathrm{pH}$ was allowed to vary. The effect of the loss of INS $\mathrm{Ca}$ on the properties of $\mathrm{CM}$ can be viewed in the context of the dual-binding model for CM (Horne, 1998). Attractive hydrophobic interactions, Ca phosphate crosslinks, and electrostatic interactions are the main forces that help maintain the internal stability of CM. Horne (1998) proposed that electrostatic repulsion and hydrophobic interactions can be viewed as being in balance; that is, if electrostatic repulsion decreases, then the effects of hydrophobic interactions are felt as an increase in attraction between $\mathrm{CN}$ residues. Modification of the attractive or repulsive interactions modulates $\mathrm{CN}$ interactions and micelle integrity (Horne, 1998). Therefore, the loss of INS Ca from within CM should reduce the number of $\mathrm{Ca}$ phosphate crosslinks, and should modify the localized balance between hydrophobic interaction and electrostatic repulsion. It is also possible that the loss of INS Ca exposes charged phosphoserine groups that would increase the local electrostatic repulsion between CN (Lucey et al., 2003). It was our hypothesis that modifications of internal $\mathrm{CM}$ interactions could affect the gelation properties of rennet-induced gels.

Significant amounts of INS Ca content were dissolved from $\mathrm{CM}$ with a reduction in $\mathrm{pH}$ (Table 1), and by the addition of EDTA to milk (Table 2), which is in agreement with many previous studies (Dalgleish and Law, 1989). The highest GM of rennet-induced gels made at different $\mathrm{pH}$ values occurred at $\mathrm{pH} 6.4$, not $\mathrm{pH}$ 6.7 (Figure 1a). Although there was only a small amount loss of INS Ca during acidification of milk from 6.7 to $\mathrm{pH} 6.4$ (Table 1), there was a substantial reduction in electrostatic repulsion due to the reduction in zeta potential (Walstra and Jenness, 1984). In this $\mathrm{pH}$ range it appears that the reduction in electrostatic repulsion more than compensated for the small loss of INS Ca, 

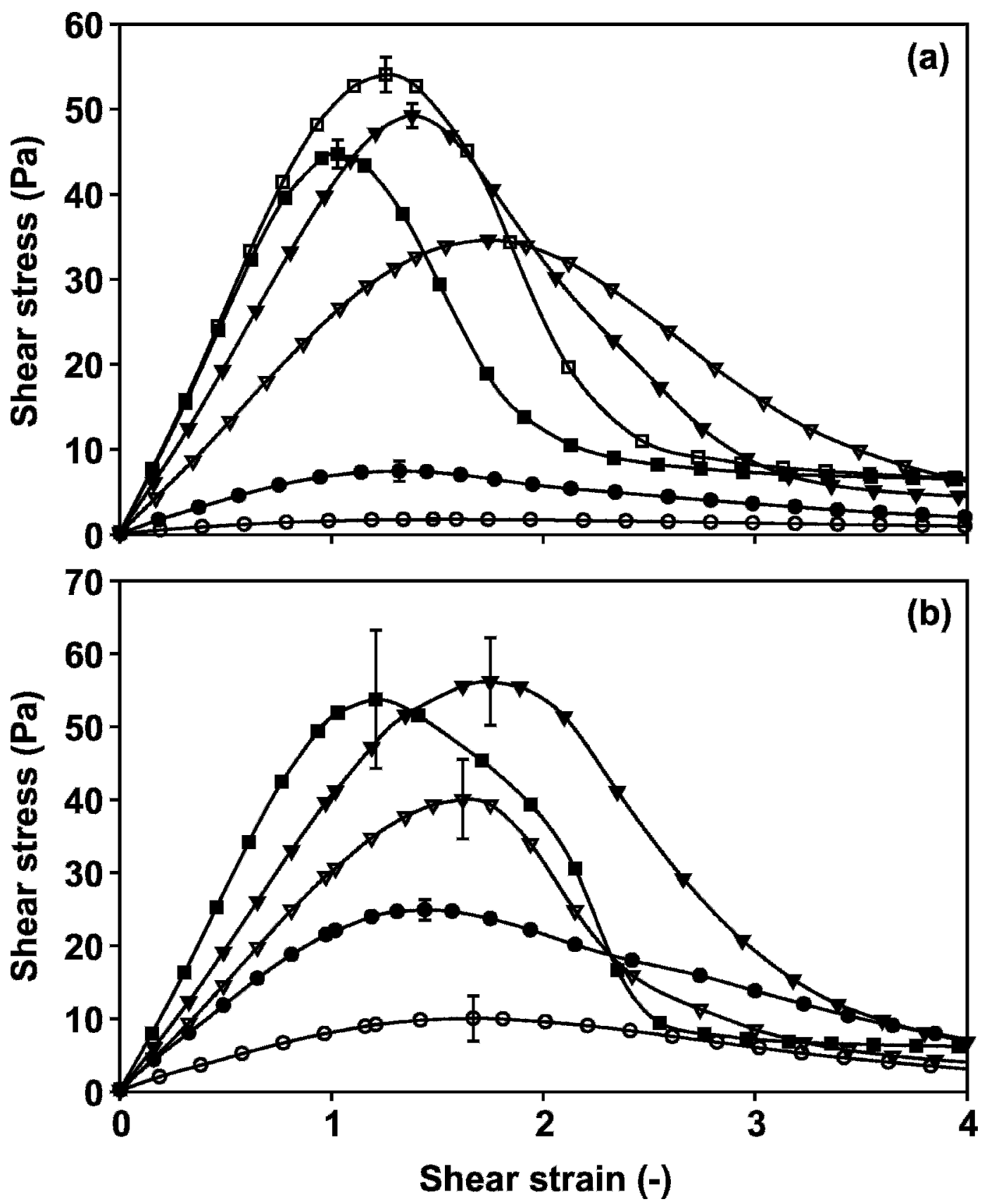

Figure 3. Shear stress as a function of applied deformation (strain) at a constant shear rate $\left(\sim 0.01 \mathrm{~s}^{-1}\right)$ for a) rennet-induced milk gels made from milk acidified to $\mathrm{pH} 6.7(\square), 6.4(\square), 6.0(\nabla), 5.8(\nabla), 5.6(\bullet)$, and pH 5.4 (O); b) rennet gels made with different EDTA levels and subsequently adjusted to pH 6.0; normal milk at pH $6.7(\boldsymbol{\square})$, and milk at pH 6.0 with $0(\boldsymbol{\nabla}), 2(\nabla), 4(\bullet)$, and 6 mM $(\bigcirc)$ added EDTA. Results are means of triplicates with error bars for standard deviation.

resulting in milk at $\mathrm{pH} 6.4$ having the highest GM value (Figure 1a). Therefore, this can be viewed as having the net interaction balance shifted in favor of enhanced attractive hydrophobic interactions. The GM values of gels decreased as milk $\mathrm{pH}$ values were reduced from 6.4 to 5.4. This was probably due to extensive loss of INS Ca (Table 1), which reduced the number of attrac- tive INS Ca crosslinks. This trend was confirmed in rennet gels made from milk that had EDTA added and in which the milk $\mathrm{pH}$ values were all adjusted to $\mathrm{pH}$ 6.0. This addition of EDTA caused the loss of attractive INS Ca bridges, which weakened the gels. As a result of the decreased attractive interaction and possibly increased electrostatic repulsion (although this might be 

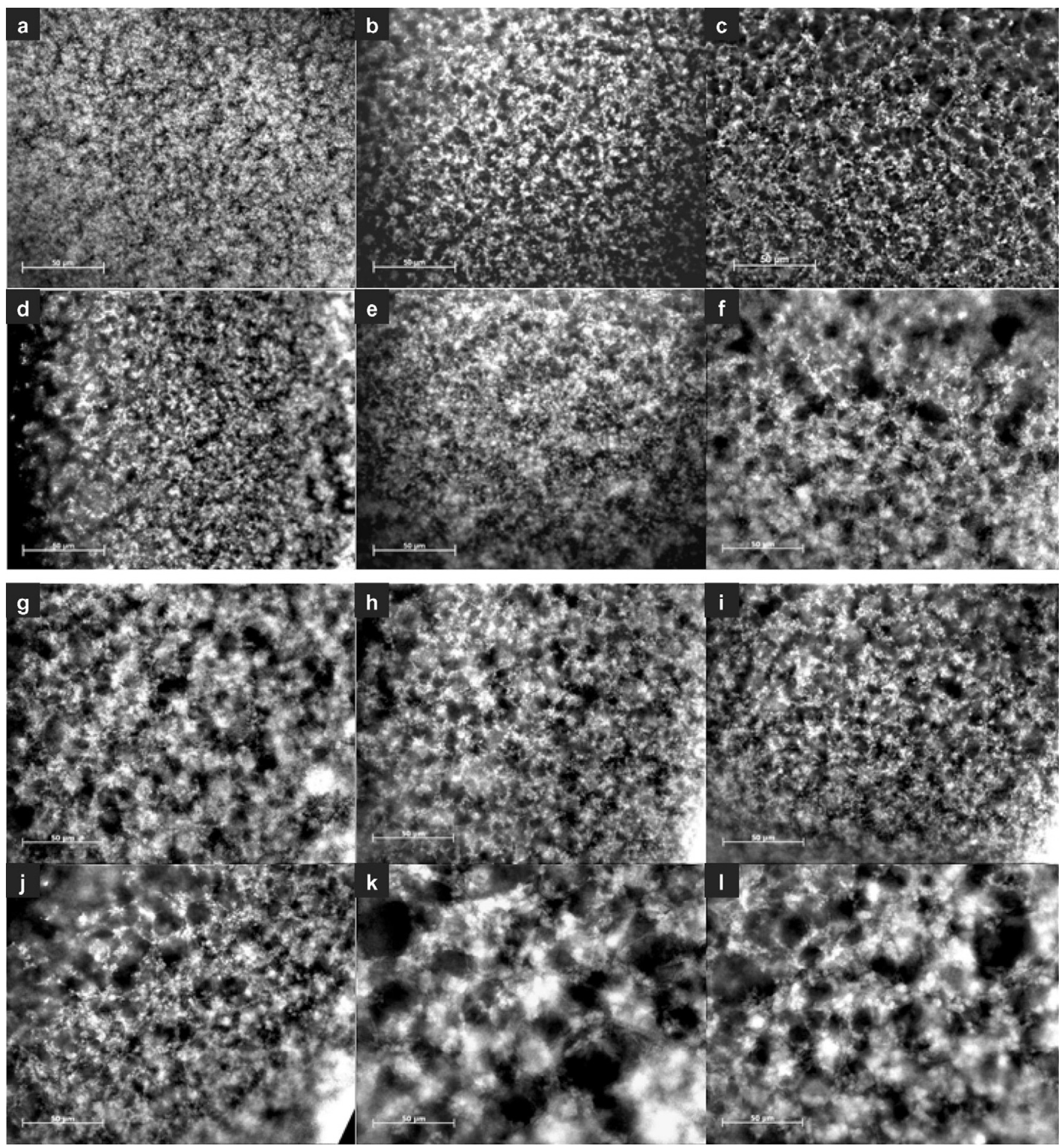

Figure 4. Microstructure of rennet-induced gels made from milk at different acidification $\mathrm{pH}$ values examined at the time of the maximum value for storage modulus $\left(\mathrm{G}^{\prime}\right)$, milk at pH $6.7(\mathrm{a}), 6.4(\mathrm{~b}), 6.0(\mathrm{c}), 5.8(\mathrm{~g}), 5.6(\mathrm{~h})$, and $5.4(\mathrm{i})$, and gels examined between 2 and $6 \mathrm{~h}$ after this maximum in $\mathrm{G}^{\prime}$, milk at $\mathrm{pH} 6.7$ (d), $6.4(\mathrm{e}), 6.0(\mathrm{f}), 5.8(\mathrm{j}), 5.6(\mathrm{k})$, and $5.4(\mathrm{l})$. The protein matrix is white and pores are dark. Scale bar $=50 \mu \mathrm{m}$. 

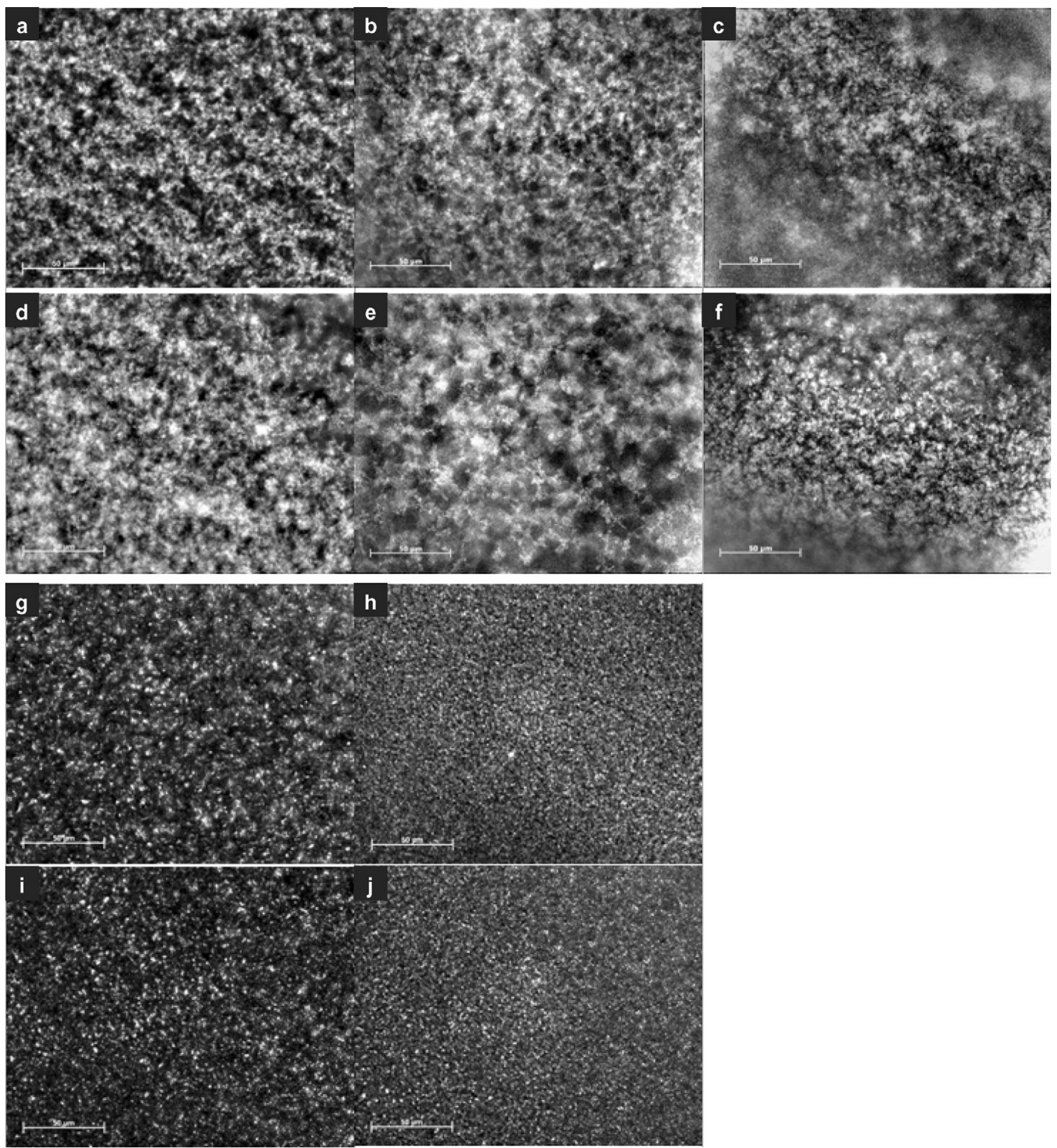

Figure 5. Microstructure of rennet-induced gels made with different EDTA concentrations examined at the time of maximum value for the storage modulus $\left(\mathrm{G}^{\prime}\right)$, milk at $\mathrm{pH} 6.7$ (a), and milk at $\mathrm{pH} 6.0$ with $0(\mathrm{~b}), 2(\mathrm{c}), 4(\mathrm{~g})$, and $6 \mathrm{~m} M(\mathrm{~h})$ added EDTA, and gels examined between 3 and $10 \mathrm{~h}$ after this maximum in $\mathrm{G}^{\prime}$, milk at $\mathrm{pH} 6.7$ (d), and milk at pH 6.0 with 0 (e), 2 (f), 4 (i), and 6 mM (j) added EDTA. The protein matrix is white and pores are dark. Scale bar $=50 \mu \mathrm{m}$. 
less important because these samples had a constant $\mathrm{pH}$ value), the GM values decreased with an increase in EDTA concentration from 0 to $2 \mathrm{mM}$ (Figure 2a). The GM values for gels made from milk with $4 \mathrm{mM}$ added EDTA were similar to those with $2 \mathrm{~m} M$ EDTA. This could be due to the very long aging time it took to reach GM; milks with $4 \mathrm{mM}$ EDTA needed 1,635 min to reach GM, whereas the milk with $2 \mathrm{~m} M$ EDTA took only $335 \mathrm{~min}$. The extremely long aging time given to the $4 \mathrm{~m} M$ EDTA sample might have allowed greater bond formation, rearrangement, or micelle fusion. The loss of internal INS $\mathrm{Ca}$ bonds as indicated by higher LT (Figure 2b) should loosen the integrity of CM and should also promote more internal rearrangements. In contrast, gels made from milk samples with $6 \mathrm{mM}$ EDTA added only had a low GM value, presumably because of excessive loss of INS Ca crosslinks from the CM with this level of EDTA (Table 2).

The LT parameter may indicate relaxation behavior of bonds within the time scale of the measurement (Zoon et al., 1989; van Vliet et al., 1991). Higher LT values indicate an increased susceptibility for rearrangements. The LT values at GM increased with a reduction in milk $\mathrm{pH}$ (Figure 1b) and with an increase in the concentration of EDTA added to milk (Figure 2b). This suggests that weaker, more flexible CN networks were formed in gels made from milk in which the CM had lower INS Ca content. The microstructure of gels made at $\mathrm{pH} 6.4$ (Figure 4b) and 6.0 (Figure 4c) had smaller pores compared with gels made at $\mathrm{pH} 5.8$ (Figure $4 \mathrm{~g}$ ), 5.6 (Figure 4h), and 5.4 (Figure 4i). The trends from the micrographs agreed with the lower GM, higher LT, and lower yield stress values obtained in low $\mathrm{pH}$ milk samples. Yield stress decreased with a reduction in INS $\mathrm{Ca}$ of CM (Figure 3), which may be attributed to occurrence of large pores and weaker interactions between CN particles (Lucey et al., 1997). There was a decrease in apparent interconnectivity between strands and clusters in the gel microstructure during aging (Figures 4 and 5), probably due to rearrangements and microsyneresis (probably aided by ongoing proteolysis). This observation agreed with the decrease in $\mathrm{G}^{\prime}$ during aging (results not shown).

The formation of rennet-induced milk gels has been considered as an adhesive hard sphere particle gel (de Kruif, 1998). The hard sphere model ignores the internal structure and bonding within the CM (de Kruif, 1998). This adhesive hard sphere models predict that $\mathrm{pH}$ controls stickiness of the hairs ("brush") of CM; that is, the lower the $\mathrm{pH}$, the stickier or less repulsive the $\mathrm{CM}$. The results of the present study suggest that the internal integrity plays a critical role in the rheological and microstructural properties of rennet gels. In this study, it was found that the dual-binding model for CM (Horne, 1998) was useful in explaining the effect of altering $\mathrm{pH}$ and INS Ca content on the properties of rennet gels.

\section{CONCLUSIONS}

This study demonstrated that the INS Ca content of $\mathrm{CM}$ has a major effect on the rheological properties of rennet-induced gels. This indicates that internal structural features are important for the properties of these gels and that hard sphere particle gel models do not predict this behavior, which is a limitation of these "surface" models. The loss of INS Ca reduced CN crosslinking and may have increased repulsion between the newly exposed phosphoserine residues, resulting in weaker gels. The loss of INS Ca also increased the LT values of gels, indicating an increase in the mobility of bonds in the network. In this study altering the internal micellar CN interactions altered the properties of rennet-induced gels, and presumably the properties of cheeses made from these gels.

\section{ACKNOWLEDGMENTS}

The financial support of Dairy Management Inc. (Rosemont, IL) is greatly appreciated.

\section{REFERENCES}

Carl Zeiss Vision. 2000. AxioVision 3.1 Reference. Carl Zeiss Vision $\mathrm{GmbH}$, Munchen-Hallbergmoos, Germany.

Choi, J., D. S. Horne, M. E. Johnson, and J. A. Lucey. 2004. Effects of insoluble calcium phosphate on cheese functionality. J. Dairy Sci. 87(Suppl. 1):231. (Abstr.)

Choi, J., and K. F. Ng-Kwai-Hang. 2003. Effects of genetic variants of $\kappa$-casein and $\beta$-lactoglobulin and heat treatment on coagulating properties of milk. Asian-australas. J. Anim. Sci. 16:1212-1217.

Esteves, C. L. C., J. A. Lucey, and E. M. V. Pires. 2001. Mathematical modelling of the formation of rennet-induced gels by plant coagulants and chymosin. J. Dairy Res. 68:499-510.

Dalgleish, D. G. 1992. The enzymatic coagulation of milk. Pages 579619 in Advanced Dairy Chemistry. 2nd ed, P. F. Fox, ed. Elsevier Applied Science, London, UK.

Dalgleish, D. G., and A. J. R. Law. 1989. pH-induced dissociation of bovine casein micelles. II. Mineral solubilization and its relation to casein release. J. Dairy Res. 56:727-735.

de Kruif, C. G. 1998. Supra-aggregates of casein micelles as a prelude to coagulation. J. Dairy Sci. 81:3019-3028.

Horne, D. S. 1995. Scaling behavior of shear moduli during the formation of rennet milk gels. Pages 456-461 in Food Macromolecules and Colloids. E. Dickinson and D. Lorient, ed. Royal Society of Chemistry, Cambridge, UK.

Horne, D. S. 1998. Casein interactions: Casting light on the black boxes, the structure in dairy products. Int. Dairy J. 8:171-177.

Horne, D. S. 2003. Casein micelles as hard spheres: Limitations of the model in acidified gel formation. Colloids Surf. A: Physicochem. Eng. Aspects 213:255-263.

Horne, D. S., and J. M. Banks. 2004. Rennet-induced coagulation of milk. Pages 47-70 in Cheese: Chemistry, Physics, and Microbiology. Vol. 1 General Aspects. 3rd ed. P. F. Fox, T. M. Cogan, T. Guinee, and P. L. H. McSweeney, ed. Elsevier Applied Science, Amsterdam, the Netherlands. 
Hyslop, D. B. 2003. Enzymatic coagulation of milk. Pages 839-878 in Advanced Dairy Chemistry. Vol. 1. (Part B). 3rd ed. P. F. Fox and P. L. H. McSweeney, ed. Kluwer Academic/Plenum, New York, NY.

Lucey, J. A., and P. F. Fox. 1993. Importance of calcium and phosphate in cheese manufacture: A review. J. Dairy Sci. 76:1714-1724.

Lucey, J. A., M. E. Johnson, and D. S. Horne. 2003. Perspectives on the basis of the rheology and texture properties of cheese. J. Dairy Sci. 86:2725-2743.

Lucey, J. A., C. T. Teo, P. A. Munro, and H. Singh. 1997. Rheological properties at small (dynamic) and large (yield) deformations of acid gels made from heated milk. J. Dairy Res. 64:591-600.

Marshall, R. T. 1992. Standard methods for the examination of dairy products. 16th ed. Am. Public Health Assoc., Washington, DC.

Mellema, M., J. W. M. Heesakkers, J. H. J. Van Opheusden, and T. van Vliet. 2000. Structure and scaling behavior of aging rennetinduced casein gels examined by confocal microscopy and permeametry. Langmuir 16:6847-6854.

Mellema, M., P. Walstra, J. H. J. van Opheusden, and T. van Vliet. 2002. Effects of structural rearrangements on the rheology of rennet-induced casein particle gels. Adv. Colloid Interf. Sci. 98:25-50.

Roefs, S. P. F. M., T. van Vliet, H. J. C. M. van den Bijgaart, A. E. A. de Groot-Mostert, and P. Walstra. 1990. Structure of casein gels made by combined acidification and rennet action. Neth. Milk Dairy J. 44:159-188.

SAS Institute. 2001. SAS/STAT User's Guide. Statistics. Version 8.2 Ed. SAS Institute Inc., Cary, NC.
Schaefer, L. H., D. Schuster, and H. Herz. 2001. Generalized approach for accelerated maximum likelihood based image restoration applied to three-dimensional fluorescence microscopy. J. Microsc. 204:99-107.

Srinivasan, M., and J. A. Lucey. 2002. Effects of added plasmin on the formation and rheological properties of rennet-induced skim milk gels. J. Dairy Sci. 85:1070-1078.

Udabage, P., I. R. McKinnon, and M. A. Augustin. 2001. Effects of mineral salts and calcium chelating agents on the gelation of renneted skim milk. J. Dairy Sci. 84:1569-1575.

van Hooydonk, A. C. M., I. J. Boerrigter, and H. G. Hagedoorn. 1986. $\mathrm{pH}$-induced physicochemical changes of casein micelles in milk and their effect on renneting. 2. Effect of $\mathrm{pH}$ on renneting of milk. Neth. Milk Dairy J. 40:297-313.

van Vliet, T., H. J. M. van Dijk, P. Zoon, and P. Walstra. 1991. Relation between syneresis and rheological properties of particle gels. Colloid Polym. Sci. 269:620-627.

Verveer, P. J., M. J. Gemkow, and T. M. Jovin. 1999. A comparison of image restoration approaches applied to three-dimensional confocal and wide-field fluorescence microscopy. J. Microsc. 193:50-61.

Vetier, N., S. Banon, J.-P. Ramet, and J. Hardy. 2000. Casein micelle solvation and fractal structure of milk aggregates and gels. Lait 80:237-246.

Walstra, P., and R. Jenness. 1984. Dairy Chemistry and Physics. John Wiley \& Sons, New York, NY.

Zoon, P., T. van Vliet, and P. Walstra. 1989. Rheological properties of rennet-induced skim milk gels. 4. The effect of $\mathrm{pH}$ and sodium chloride. Neth. Milk Dairy J. 43:17-34. 